\title{
The Tragic Vision in the Fair Youth Group in Shakespeare's Sonnets
}

\author{
Fenghua Ma \\ School of Foreign Languages, Jiangsu University, 212013, Zhenjiang, China
}

\begin{abstract}
The present paper explores the tragic vision reflected in the poet's relationship with the fair young man in the Fair Youth group in Shakespeare's Sonnets. It investigates into the cult of friendship in the Renaissance, and further analyzes Shakespeare's attitude towards the true friendship. On the basis of the poet's artistic criteria and his purpose of living, it also examines the causes of the poet's change in his attitudes, namely, from confidence to melancholy, if not despair.
\end{abstract}

Index Terms — tragic vision, friendship, Fair Youth, Shakespeare's Sonnets

\section{INTRODUCTION}

Although William Shakespeare dedicated his genius chiefly to the stage, he ranks with the foremost English poets of his age for his narrative and lyric verse. In the year of 1609, when a quarto containing 154 poems, entitled Shakespeare's Sonnets, was issued by Thomas Thorpe, a publisher, perhaps without authorization from the poet, nobody could imagine that this little volume would arouse so much attention from both readers and scholars.

Let there be furious debate on identity, date, and order concerning these sonnets, critics tend to agree that "the direction of address of these poems can be established with certainty: the first 126 sonnets refer to and are generally addressed to the Fair Friend, while the succeeding ones concern the Dark Lady" (Dubrow, 1998, p.238). Focusing on the Fair Youth group, this paper endeavors to probe into the tragic vision revealed in the poet's relationship with the fair young man.

\section{OF FRIENDSHIP}

\section{A. The Cult of Friendship in the Renaissance}

As an era that saw both the intellectual and economic rebirth in European civilization, the Renaissance abounds in achievements in diverse fields. Accordingly, it is no wonder that the Renaissance writers had made creative and original contribution to the field of literature. Writers and poets of this period exerted themselves unsparingly on the ever-lasting literary theme-friendship. As a matter of fact, there was a cult of friendship in the Renaissance. More often than not, writers of this time held the point of view that the ideal friendship between men was above love for a woman. If a reader means to find in the Renaissance literature, and in the minds of the Renaissance writers, a fantastically high appreciation of male friendship together with a correspondingly disdain for love towards a woman, he or she will not take much trouble. In their writings, Montaigne, Lyly, Sidney, and Spenser produce abundant evidence for this ideal friendship with no reluctance. For instance, Montaigne, in his renowned "Of Friendship", draws the comparison of the affection towards a woman to a "fire" and a "fever", which is "more eager and more sharp: but withal 'its more precipitant, fickle, moving and inconstant" (Hazlitt, 2011, p. 28); on the other hand, he compares the true friendship to "a general and universal fire, but temperate and equal; a constant established heat, all gentle and smooth, without poignancy or roughness" (Hazlitt, 2011, p. 28).

\section{B. "You Are My All the World":The Fair Youth to the Poet}

By looking back on the prevailing viewpoints on the friendship in the Renaissance, we get to realize how noble and lofty the true friendship was in the minds of people of that time. As one leading member of the Renaissance writers, Shakespeare, in his sonnets, clarified, in all frankness, his keen insight into this delicate human relationship.

Michel de Montaigne put his heartfelt love for his friend Étienne de la Boétie and the inconsolable grief he suffered many years after la Boétie's death in his "Of Friendship". In Shakespeare's sonnets, the poet's love towards the Fair Youth is no less intense, no less sincere. He addresses the bulk of his sonnets to the male friend with genuine and passionate devotion. However, the assumption that there is a homosexual element in their relationship may not be well grounded. As passionate friendship is a mark of the Renaissance, "the words, 'love' and 'lover' in Elizabethan English has been used for 'friendship' and 'friend"' (Marydass, 1987, p.77). The term "lover" in Shakespeare's day meant more than the exclusively sexual implication that it has today. Edward Hubler (1952), in The Sense of Shakespeare's Sonnets, also indicated that the Elizabethans were more than ready to use the term "lover" between men. For example, in Shakespeare's The Tragedy of Coriolanus, Menenius refers to Coriolanus as his "lover" in public with no hesitation 
(Act 5, Scene 2) (Wilson, 1960, p.110). It is obvious that the "lover" here means anything but homosexual. Similarly, the love in the sonnets is not homosexuality but an incarnation of the then popular cultural norms: considering an admirable male friend as an ennobling and purifying force. These facts should be kept in mind when reading the sonnets dedicated to the Fair Friend.

Shakespeare thinks highly of true friendship. As far as the sonnet sequence is concerned, the poet claims that,

Love is not love

Which alters when it alteration finds,

Or bends with the remover to remove:

O no, it is an ever-fixed mark

That looks on tempests and is never shaken;

It is the star to every wandering bark,

Whose worth's unknown, although his height be taken.

Love's not Time's fool, though rosy lips and cheeks

Within his bending sickle's compass come:

Love alters not with his brief hours and weeks,

But bears it out even to the edge of doom.

(Sonnet 116) (Wilson, 1966, p.60)

This poem makes a simple and clear definition of love (the sublime and ideal notion of true friendship), which also generously reveals itself in a great number of lines devoted to the Fair Friend.

While reading these poems, a reader just cannot fail to notice that some of them reflect a concern about the hostile or mocking world, in which the friendship dwells. Among those complaints about the bad days, Sonnet 66, which offers a catalog of what is wrong with the corrupt world, is the most celebrated one:

Tired with all these, for restful death I cry:

As, to behold desert a beggar born,

And needy nothing trimmed in jollity,

And purest faith unhappily forsworn,

And gilded honour shamefully misplaced,

And maiden virtue rudely strumpeted,

And right perfection wrongfully disgraced,

And strength by limping sway disabled,

And art made tongue-tied by authority,

And folly doctor-like controlling skill,

And simple truth miscalled simplicity,

And captive good attending captain ill.

Tired with all these, from these would I be gone,

Save that, to die, I leave my love alone. (Wilson, 1966, p.35)

The world disappoints the poet. Thinking of the world's corruption leads him to anticipate his own decay and death. This poem enjoys a great similarity with Hamlet's noted monologue, in which, with grief and indignation, he rebukes the ill phenomena that dominate Denmark:

For who would bear the whips and scorns of time,

Th' oppressor's wrong, the proud man's contumely,

The pangs of disprized love, the law's delay,

The insolence of office, and the spurns

The patient merit of th' unworthy takes...

(Act 3, Scene 1) (Wilson, 1954, p.60)

The world is "vile" (Sonnet 71) (Wilson, 1966, p.38) and full of murder, bloodiness, savageness, lies, and biases. With reference to several poems like Sonnet 29, and Sonnets 110-12, there is not much difficulty in detecting that the poet is a man of a comparatively low social status and a victim of the adverse circumstances. It seems that the poet suffers a lot in his unfortunate life. He is "made lame by fortune's dearest spite" (Sonnet 37) (Wilson, 1966, p.21). For example, Sonnet 29 displays him as a man who is "in disgrace with fortune and men's eyes" (Wilson, 1966, p.17); while in Sonnet 110, he confesses that it is true he has gone here and there, and made himself "a motley to the view" (Wilson, 1966, p.57). In Sonnet 112, the poet speaks of a "vulgar scandal stamp'd upon my brow" (Wilson, 1966, p.58), which is a brand of infamy, received from "the guilty goddess", who "did not better for my life provide than public means which public manners breeds" (Sonnet 111) (Wilson, 1966, p.58). True, the poet is fully aware that the world around him is degrading, the circumstances are unfavorable, and impediments of one kind or another will inevitably crop up on the way ahead, but, he pays no attention to them. To him, what matters is not the earthly vanity- high position, a great fortune, costly dress and things of this kind, but the true love of his friend, which is probably the only thing the poet desires. The harder the time is, the more precious the friendship becomes to him. As a result, facing adversities of various kinds, he still bears the courage to declare boldly that, the love of the Fair Youth is

better than high birth to me, 
Richer than wealth, prouder than garments' cost,

Of more delight than hawks or horses be;

And having thee, of all men's pride I boast-

Wretched in this alone, that thou mayst take

All this away and me most wretched make.

(Sonnet 91) (Wilson, 1966, p.48)

Likewise, when he is "in disgrace with fortune and men's eyes", on the thought of the fair young man, his outcast state "like to the lark at break of day arising from sullen earth, sings hymns at heaven's gate", and then he "scorns to change my state with kings" (Sonnet 29) (Wilson, 1966, p.17). Now that the Fair Friend is "my all the world" (Wilson, 1966, p.58), as the poet claims in Sonnet 112, he can endure any suffering but the loss of his friendship. Sonnet 90 carries this attitude to the extreme by beseeching the friend:

Then hate me when thou wilt, if ever, now,

Now, while the world is bent my deeds to cross,

Join with the spite of Fortune, make me bow,

And do not drop in for an after-loss.

$\mathrm{Ah}$, do not, when my heart hath 'scaped this sorrow,

Come in the rearward of a conquered woe;

Give not a windy night a rainy morrow,

To linger out a purposed overthrow.

If thou wilt leave me, do not leave me last,

When other petty griefs have done their spite,

But in the onset come; so shall I taste

At first the very worst of Fortune's might,

And other strains of woe, which now seem woe,

Compared with loss of thee will not seem so. (Wilson, 1966, p.47)

The abandonment of the Friend should come first before all the other sufferings, because the loss of the Friend will make other troubles seem less unbearable. This offers another illustration of the poet's oceanic feeling to the young man and the supreme importance of the friendship to him.

\section{FAITH IN THE FAIR FRIEND}

At the opening of the sonnet sequence, the poems create a world resonant with the friend's beauty, the poet's faithful love, his full confidence in the friend, and his optimistically ideal vision of the friendship between the youth and himself. The poet makes industrious and enthusiastic efforts to extol the beauty of his friend. Physically attractive, impressively young, and socially powerful, the fair youth incarnates nearly all the qualities that Shakespeare's culture and time values. The young man is "the world's fresh ornament" (Sonnet 1) (Wilson, 1966, p.3), the orient sun (Sonnets 7 and 33), a jewel that "Makes black night beauteous" (Sonnet 27) (Wilson, 1966, p.16), "captain jewels in the carcanet" (Sonnet 52) (Wilson, 1966, p.28), "time's best jewel" (Sonnet 65) (Wilson, 1966, p.35), the unique "exchequer" of Nature (Sonnet 67) (Wilson, 1966, p.36), and what not. Sonnet 106 gives a full expression to the friend's surpassing and dazzling outward beauty:

in the blazon of sweet beauty's best,

Of hand, of foot, of lip, of eye, of brow,

I see their antique pen would have expressed

Even such a beauty as you master now.

So all their praises are but prophecies

Of this our time, all you prefiguring...(Wilson, 1966, p.55)

There seems to be no doubt that the praise of the young man's beauty is aroused by his extraordinary appearance. But what the poet really cares is far deeper than the superficial. As Hallett Smith (1981) has purported, "Of all the themes in the sonnets, the one pursued most intently by Shakespeare is the notion of appearance, 'show', outward beauty, as contrasted with worth, 'truth', virtue" (p.65). According to the poet's perception, the measure of true worth is "within". By drawing a comparison between roses and canker blooms, Shakespeare illustrates his point of view in detail:

$\mathrm{O}$, how much more doth beauty beauteous seem

By that sweet ornament which truth doth give!

The rose looks fair, but fairer we it deem

For that sweet odour which doth in it live.

The canker blooms have full as deep a dye

As the perfumed tincture of the roses,

Hang on such thorns and play as wantonly

When summer's breath their masked buds discloses;

But, for their virtue only is their show,

They live unwooed and unrespected fade, 
Die to themselves. Sweet roses do not so;

Of their sweet deaths are sweetest odours made.

(Sonnet 54) (Wilson, 1966, p.29)

What makes a rose different from a canker bloom is that it has sweet odour. Equally, the inner worth, i.e. kindness and truth, decides whether a person who boasts a beautiful body is a true beauty or not. By no means is the mere possession of outward beauty adequate, for in Shakespeare's words,

How like Eve's apple doth thy beauty grow,

If thy sweet virtue answer not thy show!

(Sonnet 93) (Wilson, 1966, p.37)

A person, who only owns an attractive appearance but lacks inner worth, is a wolf, which translates its looks like a lamb (Sonnet 96). However, to the poet, the beauty of the young man, both external and inner, seems to be beyond all question, for he believes that what distinguishes the Fair Youth most is that he possesses virtue, which stands in sharp contrast against the demeaning real world existence. In Sonnet 105, the poet professes,

Let not my love be called idolatry,

Nor my beloved as an idol show,

Since all alike my songs and praises be

To one, of one, still such, and ever so.

Kind is my love today, tomorrow kind,

Still constant in a wondrous excellence;

Therefore my verse to constancy confined,

One thing expressing, leaves out difference.

'Fair, kind, and true' is all my argument,

'Fair, kind, and true', varying to other words;

And in this change is my invention spent,

Three themes in one, which wondrous scope affords.

Fair, kind, and true have often lived alone,

Which three till now never kept seat in one. (Wilson, 1966, p.55)

Here, “'fair' suggests beauty, justice, and kindness; 'kind', generosity, gentleness, affection, naturalness; 'true', natural integrity, spontaneous honesty, constancy, true rather than feigned beauty" (Kerrigan, 1986, p.311). Through these lines the poet not only clarifies his standards of "worth", but reveals his every confidence in the Fair Youth. As far as the poet is concerned, "Fair, kind, and true" are the intrinsic qualities of the fair young man. As a matter of fact, "Fair, kind, and true", especially, "true", and the unity of the three are the poet's ideals, his artistic criteria as well as his ultimate goals of life.

The words "true" and "truth", take up "a predominant position in the sonnets of Shakespeare" (Ellrodt, 1994, p.90). In most cases, the "truth" quality is identified with constancy. Sonnet 53 shares the similar theme with Sonnet 105, in which the poet glorifies both the physical and the inner beauty of his friend,

Describe Adonis, and the counterfeit

Is poorly imitated after you;

On Helen's cheek all art of beauty set,

And you in Grecian tires are painted new.

Speak of the spring and foison of the year;

The one doth shadow of your beauty show,

The other as your bounty doth appear,

And you in every blessed shape we know. (Wilson, 1966, p.29)

The couplet

In all external grace you have some part,

But you like none, none you, for constant heart. (Wilson, 1966, p.29)

Sheds some light on the poet's confidence in his friend. Not only is the Fair Youth externally handsome, but he has surpassing "worth" - constancy as well, for which he exceeds any beauty else. The poet, in Sonnets 25 , contrasts his situation with that of people who can boast of public honor and proud titles, with great prince's favorites, with military heroes. Though the sonnet starts with a tone of complaint about obscurity of his birth and sufferings of all kinds but ends with heartfelt happiness. For the trust in the friend's constancy, the poet does not really envy those vanities that may vanish without a trace sooner or later, and can announce proudly:

Then happy I, that love and am beloved

Where I may not remove nor be removed. (Wilson, 1966, p.15)

$\mathrm{He}$ is content with the mere fact that his love is returned by the Friend. The Fair Friend is his everything. He is the strength and hope for the poet to carry on struggles in his life which is bitter and frustrating.

Besides the meaning of "constancy", the word "truth" can also mean "authenticity", "the artistic criterion of Shakespeare" (Tu, 1981, p.164). During the Renaissance, the sixteenth century in particular, poets turned out thousands of sonnets. Thanks to the sonnets of Petrarch and his disciples, poets of the present age, more often than not, sing to the 
pale moon, the limpid fountains, the brief rose of spring, and the wounding child-god of Love. It is common for poets of the time to utilize Petrarchan conceit to extol their lovers. Shakespeare seems to be "a rebel in the tradition of the Renaissance sonnet" (Gowda, 1986, p.136). In his sonnets, the poet places a strong emphasis upon the poetic "truth", and presents repulsion towards the poetic exaggeration at the same time. Sidney deals with this grandiloquent fashion of the time seriously in his Defence of Poesy.

"But truly many of such writings as come under the banner of irresistible love, if I were a mistress, would never persuade me they were in love: so coldly they apply fiery speeches, as men that had rather read lovers' writings-and so caught up certain swelling phrases which hang together like a man that once told my father that the wind was at northwest and by south, because he would be sure to name winds enough - than that in truth they feel those passions, which easily (as I think) may be betrayed by that same forcibleness or energia (as the Greeks call it) of the writer. But let this be a sufficient, though short note, that we miss the right use of the material point of poesy.

Now for the outside of it, which is words, or (as I may term it) diction, it is even well worse, so is that honey-flowing matron eloquence appareled or rather disguised, in a courtesan-like painted affectation: one time with so farfet words, that many seem monsters - but must seem strangers - to any poor Englishman; another time with coursing of a letter, as if they were bound to follow the method of a dictionary; another time with figures and flowers extremely winterstarved" (Abrams, 1998, p.498).

To some extent, this viewpoint is identical with that of Shakespeare. With regard to Shakespeare, the poetic truth is superior to poetic praise; and nature itself triumphs anything artificial. Therefore, more than once, in his sonnets, the poet asserts that, compared with the deliberate praise in the poems,

There lives more life in one of your fair eyes

Than both your poets can in praise devise.

(Sonnet 83) (Wilson, 1966, p.44)

And more, much more, than in my verse can sit

Your own glass shows you when you look in it.

(Sonnet 103) (Wilson, 1966, p.54)

Shakespeare is disgusted at the way many poets do in their poetry. On several occasions, he rebels against the excesses of Petrarchism. Sonnet 21 is a noteworthy instance. In this poem, the poet spares no pains to refute the stereotyped comparison such as sun, moon, "earth and sea's rich gems", or "April's first-born flowers" (Sonnet 21) (Wilson, 1966, p.13). The "couplement of proud compare", to the poet, is only for the purpose to sell, and daubing the youth with verbal cosmetics, the poetic praise conceals the natural painting of what he is, to leave him a merely "painted beauty" (Sonnet 21) (Wilson, 1966, p.13). He insists on describing the Fair Friend's excellence for its simple, plain truth - "O, let me, true in love, but truly write" (Wilson, 1966, p.13), as he says in Sonnet 21, is far better than those "gross painting" (Sonnet 82) (Wilson, 1966, p.43). In his opinion, a poet with such a subject as the fair young man has no need for art, no need for figure, no need for invention, for the simple reason that the subject itself confers sufficient perfection upon verse. As a result, he proclaims staunchly,

I never saw that you did painting need,

And therefore to your fair no painting set;

I found, or thought I found, you did exceed

The barren tender of a poet's debt;

(Sonnet 83) (Wilson, 1966, p.44)

Who is it that says most which can say more

Than this rich praise - that you alone are you,

(Sonnet 84) (Wilson, 1966, p.44)

While other poets resort to "strained touches" of rhetoric, he does not follow their suit, instead, he does his utmost to fulfill his principle he always pursues,

Thou truly fair wert truly sympathized

In true plain words by thy true-telling friend;

(Sonnet 82) (Wilson, 1966, p.43)

In a larger sense, the poet regards the poetic truth as a representation of his own truth, or constancy to his Fair Friend.

In Sonnet 76, the poet admits that,

That every word doth almost tell my name,

Showing their birth and where they did proceed? (Wilson, 1966, p.40)

His verse is "so barren of new pride", "so far from variation or quick change", and lacks "new-found methods" and "compounds strange" (Wilson, 1966, p.40). In other words, his verse is not fashionable. But what makes matter worse is that, because of the plainness of his style, his individual way of expression comes into the sharpest conflict with the style as fashion. However, rather than yield to the fashion, the poet states assuredly,

$\mathrm{O}$, know, sweet love, I always write of you,

And you and love are still my argument;

So all my best is dressing old words new,

Spending again what is already spent; 
For as the sun is daily new and old,

So is my love still telling what is told.

(Sonnet 76) (Wilson, 1966, p.40)

In "triumphant, and entirely conventional, figure of the sun's faithful return after its nightly extinction, bringing light and fertility to the world each day, the poet establishes the essential nature both of his love, and of his way of expressing that love" (Colie, 1987, p.42). To the poet, his profound affection must triumph over the so-called fashion, and his loyal love towards the young man must make his poems distinguish from those of others. What matters to him are not the outward forms of variation, but the content, the feeling he attempts to express. At the beginning of the friendship between the fair young man and himself, the poet feels completely confident of his friend's understanding of his artistic pursuit and faithful love. Accordingly, in Sonnet 32, he is proud enough to imagine his friend favoring his verse, after his death, even though his poems, which are simple but sincere, are inferior to "the bett'ring of the time" (Wilson, 1966, p.18). And he believes the friend will say,

But since he died, and poets better prove,

Theirs for their style I'll read, his for his love. (Wilson, 1966, p.18)

\section{FINAL DISAPPOINTMENT IN THE FAIR YOUTH}

To sum up, the most important thing about the Fair Friend addressed in the sonnets is that he is a perfect subject for poetry. The friend is, in the opinion of the poet, a "beauty's rose" (Sonnet 1) (Wilson, 1966, p.3), of both outward fair and inner worth. In the eyes of the poet, the fair young man is his everything in a transient and degrading world as it is lived and felt by him. It is the love of the young man that lights his way. The poet's sense of himself hinges on the identification of the Fair Youth. He feels content that he loves his friend, and meanwhile, his love is returned. Yet for all his "worth" or constancy, the Fair Friend is capable of betraying with the Dark Lady (the addressee of Sonnets 127-54), as well as of turning against the poet to adopt the Rival Poet.

\section{A. The Friend's Betrayal with the Dark Lady}

Heather Dubrow (1998) has contended that, "The axiom that the first 126 poems involve the Friend and subsequent lyrics concern the Dark Lady generates assumptions about the presence of a linear plot: the poet meets the Fair Youth, and they enjoy a period of happiness; their joy is, however, shadowed by a period of absence and by the fault alluded to in Sonnet 35 ('No more be grieved at that which thou hast done') and elsewhere; the entrance of the Dark Lady, who is as untrustworthy as she is attractive, disrupts the idyll celebrated in the joyous sonnets, and she, the poet himself and the Fair Friend become embroiled in a triangle of jealousy and deceit" (p. 238). In The Two Gentlemen of Verona (1594), Shakespeare deals with the similar theme of conflict between the romantic love and the male friendship. Though the ending of this play is often denounced by the critics, Valentine's prompt pardon of Proteus' falsity and his gesture of surrendering Silvia to him, are the extreme exhibition of the ancient code of male friendship.

According to Sonnet 41 the Fair Friend, like Proteus, is doubly disloyal:

Ay me, but yet thou might'st my seat forbear,

And chide thy beauty and thy straying youth,

Who lead thee in their riot even there

Where thou art forced to break a twofold truth,

Hers, by thy beauty tempting her to thee,

Thine, by thy beauty being false to me. (Wilson, 1966, p.23)

"My seat" here is "to be understood in the same sense it bears in Othello when Iago in soliloquy gives some of his reasons for wanting revenge on Othello" (Smith, 1981, p.63). All the same, when in face of the Fair Friend's fault, the poet is just as tolerant as Valentine. But the initial idealization of the fair young man makes horrific the poet's gradual recognition of the youth's, to some extent, vicious and selfish character. The poet's ideal becomes a pathetic illusion. He becomes less optimistic and even desperate, for the simple reason that, from beginning to end, the poet deems that the male friendship counts far more than the romantic love does. Conspicuously, he is hurt by what the young man has done, and he is disappointed with him. But even in such circumstances, he still puts up with his friend's disloyalty, though deep within his heart, he is in anguish. Sonnet 40 is a good example, in which the poet exclaims,

I do forgive thy robb'ry, gentle thief,

Although thou steal thee all my poverty;

And yet love knows it is a greater grief

To bear love's wrong than hate's known injury.

Lascivious grace, in whom all ill well shows,

Kill me with spites; yet we must not be foes. (Wilson, 1966, p.22)

Here by proclaiming that "Lascivious grace, in whom all ill well shows" (Wilson, 1966, p.22), the poet, in a sense, comes to admit that the friend is not that perfect as he describes in many sonnets - he possesses something evil in his character. However the poet forgives his friend. And he even spares no efforts to defend the friend's fault. For example, in Sonnet 41, the Fair Youth's lasciviousness is excused by the poet: because of the friend's gentleness and beauty, and 
because of the invitation that comes from the woman: who will be so sourly as to turn her down? Sonnet 42 maintains the similar theme but somehow runs to an extreme:

Loving offenders, thus I will excuse ye:

Thou dost love her because thou know'st I love her,

And for my sake even so doth she abuse me,

Suff'ring my friend for my sake to approve her.

If I lose thee, my loss is my love's gain,

And losing her, my friend hath found that loss;

Both find each other, and I lose both twain,

And both for my sake lay on me this cross.

But here's the joy: my friend and I are one.

Sweet flattery! Then she loves but me alone! (Wilson, 1966, p.23)

Casuistical and less convincing, these sonnets reveal a pessimistic mood, a quality alien to those optimistic sonnets on the Fair Friend's beauty and truth. The paradoxical attitudes the poet expresses in these poems betray his exceeding agony resulted from the friend's infidelity, and disillusionment of his ideal.

\section{B. The Friend's Adoption of the Rival Poet}

Probably because of the poet's social inferiority, he and the fair young man are on delicate terms. It seems that the action, in this friendship, is almost all on the poet's side. Rosalie Colie (1987) once passed a remark on this kind of relationship, "the relation of poet to this friend is based on poetry; poetry is not only the conventional instrument of appeal to patron, friend, lover, the conventional voice in beauty's praise; but poetry is also the poet himself, ingrained in his personality and thus making (the dyer's hand) all his human realizations and relations" (p. 44) As a result, the friend's acceptance of the poetry is crucial to the poet. Once upon a time the poet is proved to be confident of the friend's understanding and favor of his poems, which resort to true feeling instead of to flowery forms and extravagant praise. Fearing no particular threat, he can say that he writes of his friend "without all ornament" (Sonnet 68) (Wilson, 1966, p.36); can say his friend's will appreciate his verse even after his death, despite that his poems are mere "poor rude lines" compared with "the bett'ring of the time" (Sonnet 32) (Wilson, 1966, p.18). But when an "alien pen" (Sonnet 78) does appear (Wilson, 1966, p.41), his confidence is at stake. To the poet's horror, the Rival Poet attracts the attention and favor of the friend, as is revealed in Sonnet 84,

You to your beauteous blessings add a curse,

Being fond on praise, which makes your praises worse. (Wilson, 1966, p.44)

The poet discovers that the lovely youth has been corrupted by those gaudy sonnets, bundles of "similes", "praise". Furthermore, ending with:

Thus have I had thee as a dream doth flatter,

In sleep a king, but waking no such matter. (Wilson, 1966, p.46)

Sonnet 87 submits evidence of the youth's apparent neglect or abandonment of the poet. These ruthless realities fail the poet and give rise to great pains in the poet's heart; pains result not only from the betrayal of the Fair Friend, but from the bankruptcy of an extremely cherished ideal. Under the deplorable circumstances, the poet is obliged to move from confidence to melancholy.

\section{CONCLUSION}

Clearly, for the poet, the poetry, as Thomas M. Greene (1987) put it, "reflects a sense of inner depletion, emptiness, poverty, which the friend is asked or stated to fill up" (p.78). The importance of the fair young man to the poet is beyond measure. In the eyes of the poet, the Fair Youth is of both outward and inner beauty, is the embodiment of "fair, kind and true"; and the poet's confidence in the friendship between this fair young man and himself is the only drive for his struggles in the bitter and tortuous life. He symbolizes all "worth" that the poet cherishes. Accordingly, the friend's betrayal with the Dark Lady and his adoption of the Rival Poet, turn the poet's ideal world down, and throw him into an abyss of agony. He gets to realize that the Fair Youth's most celebrated characteristic - truth, is, in faith, open to charges. His enthusiastic pursuit of "Fair, kind and true" criterion turns out to be a failure. The tragic ending of his quest casts an excessive gloom over the poet's initially optimistic humor and a pessimistic mood arises spontaneously.

\section{REFERENCES}

[1] Abrams, M. H. (ed.) (1998). The Norton Anthology of English Literature: Vol. I (6th ed.). New York: W.W. Norton \&. Company.

[2] Colie, R. L. (1987). Criticism and the Analysis of Craft: The Sonnets. In Shakespeare's Sonnets, 29-45. New York: Chelsea House Publishers.

[3] Hazlitt, W. C. (ed.) (2011). Michel de Montaigne: Selected Essays. C. Cotton, Trans. NY: Dover Publications Inc.

[4] Dubrow, H. (1998). Incertainties now crown themselves assur'd: The Politics of Plotting Shakespeare's Sonnet. Shakespearean Criticism 40, 238-247. 
[5] Ellrodt, R. (1994). The Inversion of Cultural Traditions in Shakespeare's Sonnets. In Shakespeare and Cultural Traditions. Selected Proceedings of the International Shakespeare Association World Congress, Tokyo 1991. Newark: University of Delaware Press.

[6] Greene, T. M. (1987). Pitiful Thrivers: Failed Husbandry in the Sonnets. In H. Bloom (eds.), Critical Interpretations: William Shakespeare's Sonnets. New York: Chelsea House Publishers.

[7] Gowda, H. H. A. (1986). Shakespeare's Comedies and Poems: A Critical Introduction. New York: Envoy Press.

[8] Hubler, E. (1952). The Sense of Shakespeare's Sonnets. Princeton, NJ: Princeton University Press.

[9] Kerrigan, J. (ed.) (1986). William Shakespeare: The Sonnets and A Lover's Complaint. London: Penguin Books.

[10] Smith, H. D. (1981). Tension of the Lyre: Poetry in Shakespeare's Sonnets. San Marino: The Huntington Library.

[11] Tu, A. (trans.) (1981). The Shakespeare's Sonnets. Shanghai: Shanghai Translation Publishing House.

[12] Wilson, J. D. (ed.) (1954). Hamlet. New York: Cambridge University Press.

[13] Wilson, J. D. (ed.) (1960). The Tragedy of Coriolanus. New York: Cambridge University Press.

[14] Wilson, J. D. (ed.) (1966). The Sonnets. New York: Cambridge University Press.

Fenghua Ma is a lecturer in the English Department, School of Foreign Languages at Jiangsu University. Her research interests include English literature and American literature. 